Volume 6, Issue 2 (Summer 2014)

\title{
Judith with the Head of Holofernes: Jan Cornelisz Vermeyen's Earliest Signed Painting
}

Maryan Ainsworth and Abbie Vandivere

\section{Recommended Citation:}

Maryan Ainsworth and Abbie Vandivere, "Judith with the Head of Holofernes: Jan Cornelisz Vermeyen's Earliest Signed Painting, “ JHNA 6:2 (Summer 2014), DOI: 10.5092/jhna.2014.6.2.2 Available at https://jhna.org/articles/judith-with-the-head-of-holofernes-jan-cornelisz-vermeyenearliest-signed-painting/

Published by Historians of Netherlandish Art: https://hnanews.org/

Republication Guidelines: https://jhna.org/republication-guidelines/

Notes: This PDF is provided for reference purposes only and may not contain all the functionality or features of the original, online publication. This is a revised PDF that may contain different page numbers from the previous version. Use electronic searching to locate passages. This PDF provides paragraph numbers as well as page numbers for citation purposes.

ISSN: 1949-9833 


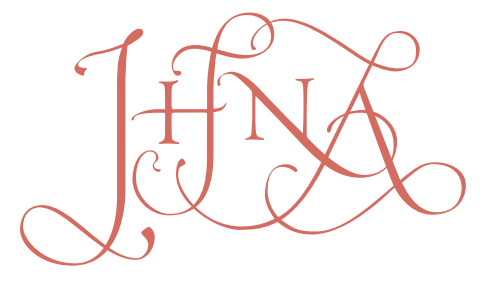

\title{
JUDITH WITH THE HEAD OF HOLOFERNES: JAN CORNELISZ VERMEYEN'S EARLIEST SIGNED PAINTING
}

\author{
Maryan Ainsworth and Abbie Vandivere
}

This article presents a new attribution and dating for a painting of Judith with the Head of Holofernes. A monogram, decorative elements, and technical features strongly suggest that it was made by Jan Cornelisz Vermeyen around 1525-30.The decorative details are placed within the context of contemporary sketchbooks and pattern books. The painting technique -- including preparatory layers, brushwork, and the depiction of fabrics -- is discussed in relation to other paintings by Vermeyen and Jan Gossart. The subject matter of the powerful female figure gives clues to the painting's likely patron: Margaret of Austria, regent of the Netherlands. D0I: 10.5092/jhna.2014.6.2.2

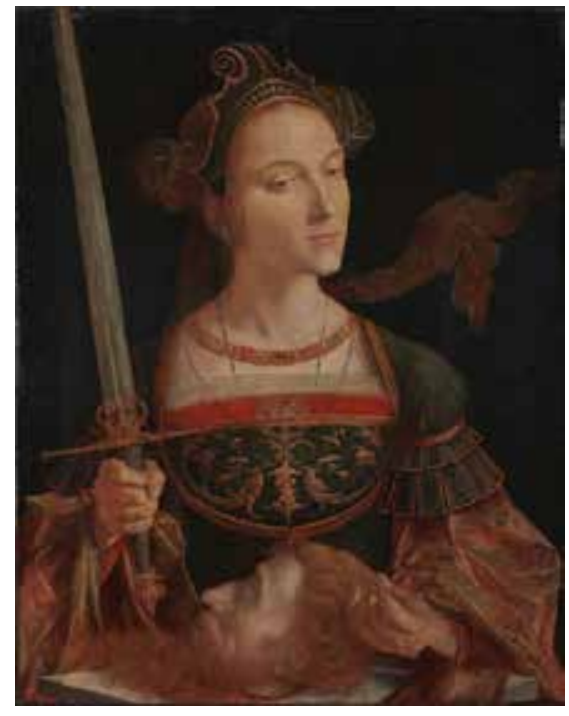

Fig 1 Jan Cornelisz. Vermeyen, Judith with the Head of Holofernes, ca. 1525-30, oil on panel, $63.5 \times 47.3 \mathrm{~cm}$. Private collection (Photo: Paintings Conservation Department, Metropolitan Museum of Art) n this dramatically assertive image (fig. 1), the Old Testament figure Judith is dressed as a classical heroine in antique-style, pseudo-Roman armor, yet "decked ... bravely, to allure the eyes of all men that should see her" (Apocrypha, Judith 10:4). With her large, masculine-looking hands, Judith brazenly wields the sword she has used to sever the head of Holofernes (Judith 13), the Assyrian general whose troops had captured the Jewish city of Bethulia, and grabs the locks of her victim's hair. Self-absorbed in thought, she reflects on her triumphant deed. As a result of her actions, and demoralized by the loss of their leader Holofernes, the Assyrians fell into the hands of the Jewish armies. 


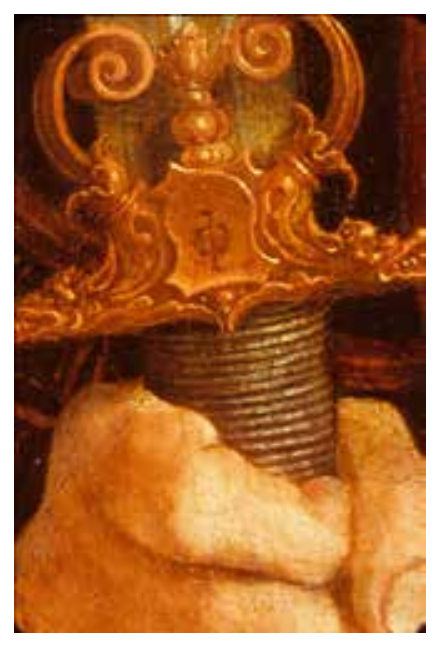

Fig 2 Jan Cornelisz. Vermeyen, detail of monogram on the hilt of the sword, Judith with the Head of Holofernes, normal light (Photo: Paintings Conservation Department, Metropolitan Museum of Art)

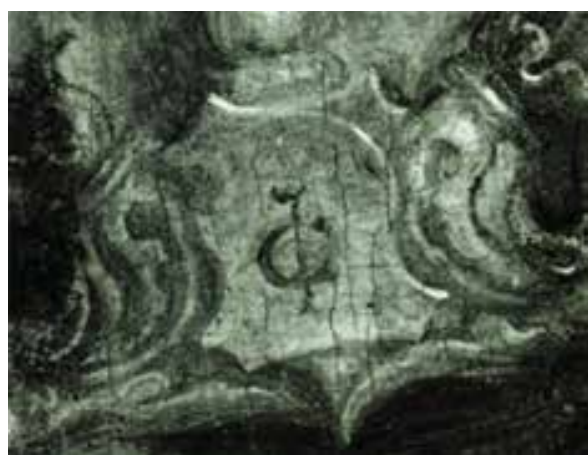

Fig 3 Jan Cornelisz. Vermeyen, detail of monogram on the hilt of the sword, Judith with the Head of Holofernes, infrared reflectogram (Photo: Paintings Conservation Department, Metropolitan Museum of Art)

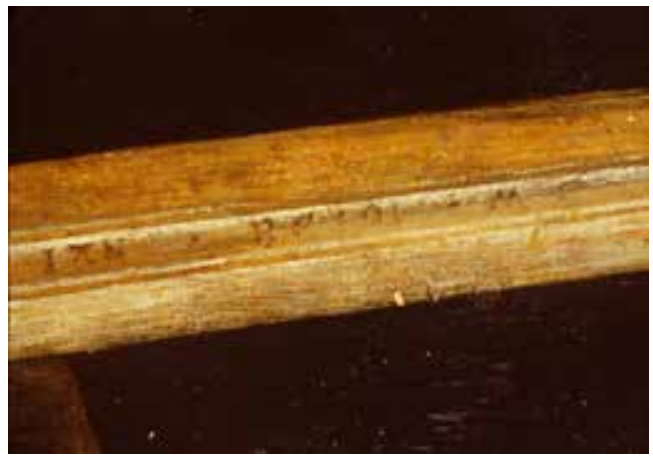

Fig 5 Jan Cornelisz. Vermeyen, detail of inscription on the shaft of the sword, Judith with the Head of Holofernes (Photo: Paintings Conservation Department, Metropolitan Museum of Art)

2 This painting in a private collection was long considered a work by Jean Bellegambe, the Franco-Flemish painter from Douai. ${ }^{1}$ However, visible on the tiny shield on the guard of the sword is the unmistakable -- albeit altered -- monogram "IC" (in ligature) of Jan Cornelisz. Vermeyen (Beverwijk, near Haarlem, ca. 1502-1559 Brussels). The infrared reflectogram of this monogram shows its original form, which at a later point was modified for unknown reasons when the " $C$ " was overpainted to make an "O" (compare figs. 2 and 3). ${ }^{2}$ Here we find the intertwined letters "IC" in the form Jan used to sign his prints and only one other painting, The Holy Family, where he painted his "IC" monogram beneath the inscription "IOHNES VERMEI PI[N] GEBAT" (fig. 4). Further confirming Vermeyen's authorship of the Judith is the damaged inscription on the shaft of the sword (fig. 5). It reads "IAN BE ... [?] M" followed by a star. Although the IAN confirms the artist's first name, the second word is unintelligible; possibly it once indicated, in abbreviated form, "Bevervicanum," the Latin form of Beverwijk, Vermeyen's birthplace.

3 The dating of the painting to around 1525-30 is supported by the painting's relationship to Vermeyen's other early works, namely, Cardinal Érard de la Marck and the Holy Family diptych of circa 1530 (discussed below). In addition, the details of Judith's antique-style, pseudo-Roman armor and headdress also suggest this date, as they are similar to decorative features that appear 
in contemporary sketchbooks and pattern books. Very close to Vermeyen's ornamental motifs are those found in the earliest known sketchbook from the Netherlands, namely, the so-called Berlin Sketchbook attributed to Jacob Cornelisz. van Oostsanen and his workshop. ${ }^{3}$ The pattern on the bodice of Judith's cuirass is comparable to various decorative forms found in this sketchbook, such as the winged angel's head (folio 13v; fig. 6), and mirrored dolphins (birds in Vermeyen's painting) whose tails turn into sprawling acanthus leaves, simulating volutes (folios $1 \mathrm{v}, 13 \mathrm{v}$, and the top of 46v; fig. 7). Two folios in this sketchbook are dated 1523 (folio 13v) and 1524 (folio $47 \mathrm{r}$ ), and other evidence indicates that some of the designs date into the 1530s, giving an indication of the general period of its use. ${ }^{4}$ Some textile pattern books from the 1520 s and 1530s, namely Peter Quentel's Eyn Newe kunstlich moetdelboech alle kunstner zu brachen of 1532, also show analogous features, including cherubs, stylized leaves, and dolphins, though none is as refined as the pattern in Judith's bodice. ${ }^{5}$

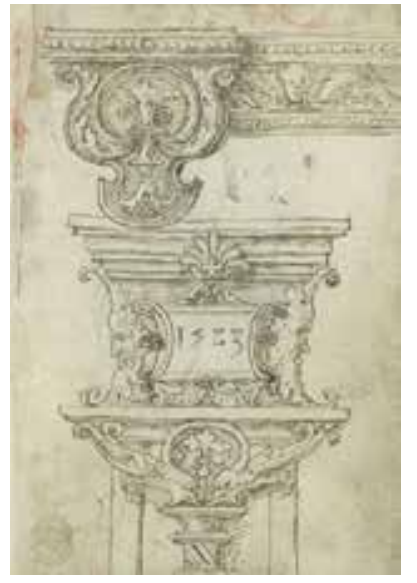

Fig 6 Jacob Cornelisz. van Oostsanen, detail of winged angel's head, Berlin Sketchbook, folio 13v. Kupferstichkabinett, Staatliche Museen zu Berlin, inv. no. 79 C 2a (Photo: Volker H. Schneider, Berlin) (artwork in the public domain)

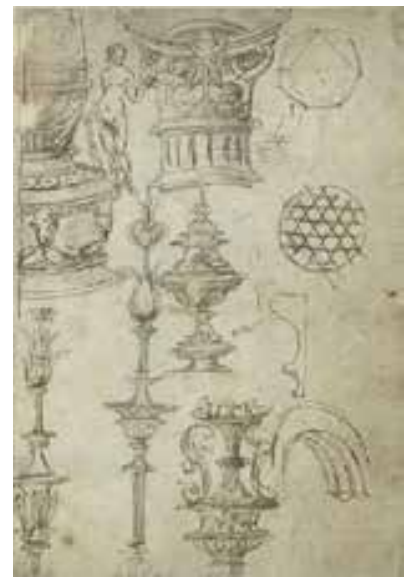

Fig 7 Jacob Cornelisz. van Oostsanen, detail of dolphins, Berlin Sketchbook, folios 1v, 13v, and the top of 46v. Kupferstichkabinett, Staatliche Museen zu Berlin, inv. no. 79 C 2a (Photo: Volker H. Schneider, Berlin) (artwork in the public domain)

One of the earliest known printed pattern books for artists is Ein frembds vnd wunderbars Kunstbuechlin, published in Strasbourg in $1538 .{ }^{6}$ These designs show antique-style armor, ladies' decorative headdresses, hand gestures, column bases, etc., and are based on earlier sources, many of which derive from late fifteenth- and early sixteenth-century German and Netherlandish art. Several of the patterns are quite similar to the headdress, armor, and even hand poses of Judith in the painting and confirm the avid interest at the time in the all'antica style (figs. 8, 9, 10).

To date, less attention has been paid to the paintings of Vermeyen than they merit. Two early articles, one by Otto Benesch focusing on Vermeyen's portraits and another by Kurt Steinbart, attempted to bring some clarity to the painted oeuvre. ${ }^{7}$ Hendrick Horn's monograph of 1989 concentrated more on the great Battle of Tunis series -- Vermeyen's important tapestry designs commissioned by Charles V -- and less on the paintings, which by the author's own admission are not presented as a catalogue raisonné. ${ }^{8}$ A 2008 Burlington Magazine article on Vermeyen's Cardinal Érard de la Marck and the Holy Family diptych, the 2010 catalogue of the works of Jan Gossart (ca. 1478-1532) and the accompanying exhibition in New York and London -- which called attention to the painter's significant influence on Vermeyen ${ }^{9}$-- and now the rediscovered 


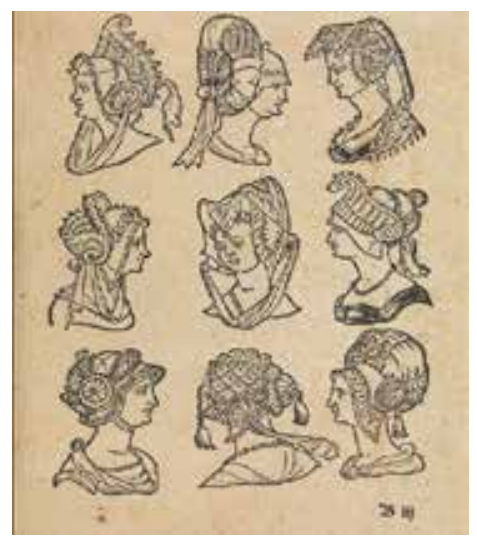

Fig 8 Details of headdresses from Ein frembds vnd wunderbars Kunstbuechlin (Strasbourg, 1538). The Metropolitan Museum of Art, New York, Rogers Fund, 1919, inv. no. 19.62.2. (artwork in the public domain)

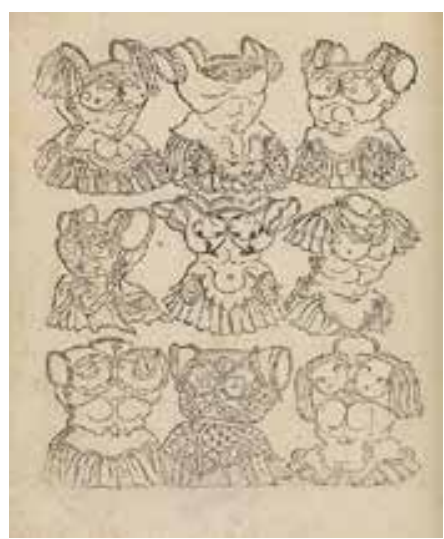

Fig 9 Details of armor from Ein frembds vnd wunderbars Kunstbuechlin (Strasbourg, 1538). The Metropolitan Museum of Art, Rogers Fund, 1919 (inv. no. 19.62.2) (artwork in the public domain)

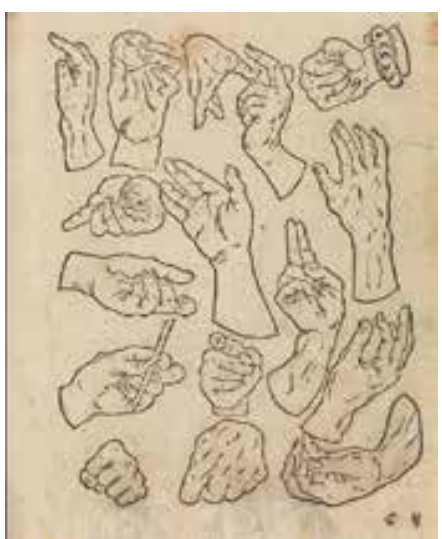

Fig 10 Details of hands from Ein frembds vnd wunderbars Kunstbuechlin (Strasbourg, 1538). The Metropolitan Museum of Art, Rogers Fund, 1919 (inv. no. 19.62.2) (artwork in the public domain)

autograph Judith with the Head of Holofernes once again urge a reconsideration of the artist's early paintings.

A number of technical and stylistic parallels can be drawn between the Judith painting and Vermeyen's Cardinal Érard de la Marck and The Holy Family (figs. 11, 12). ${ }^{10}$ The Cardinal and the Holy Family underwent conservation treatment in 2006-7, ${ }^{11}$ were included in the exhibition Prayers and Portraits: Unfolding the Netherlandish Diptych (National Gallery of Art, Washington, D.C., and Koninklijk Museum voor Schone Kunsten, Antwerp) in 2006-7, and were subsequently the subjects of the previously mentioned Burlington Magazine article. ${ }^{12}$ They were probably pendant paintings that hung next to each other on a wall, rather than being a conventional folding diptych. They were painted when Vermeyen worked for the court of Margaret of Austria in Mechelen and until now have been thought to be Vermeyen's earliest autograph paintings. It has been suggested that prior to this period of employment, Vermeyen may have trained with Jan

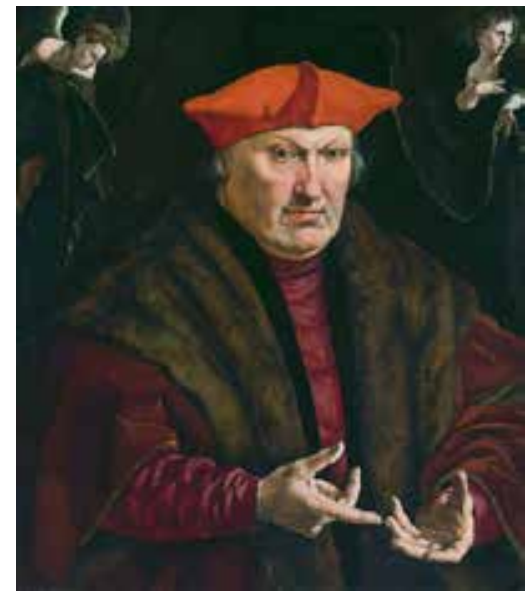

Fig 11 Jan Cornelisz. Vermeyen, Cardinal Érard de la Marck, ca. 1530, oil on panel, $63.7 \mathrm{~cm} x$ $54.5 \mathrm{~cm}$. Rijksmuseum, Amsterdam, inv. no. SK-A-4069 (artwork in the public domain)

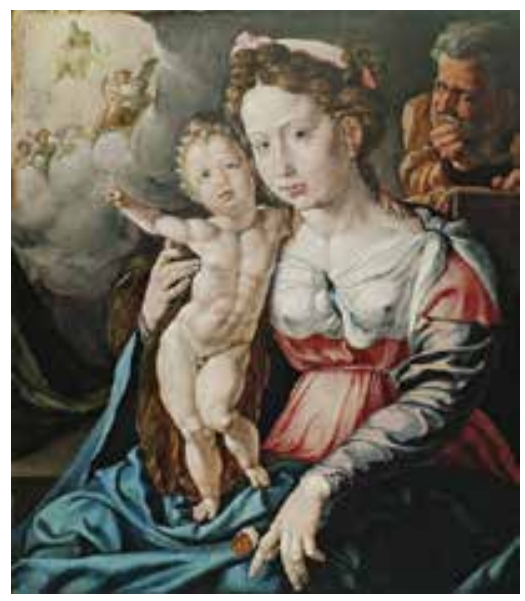

Fig 12 Jan Cornelisz. Vermeyen, Holy Family (fig. 4).

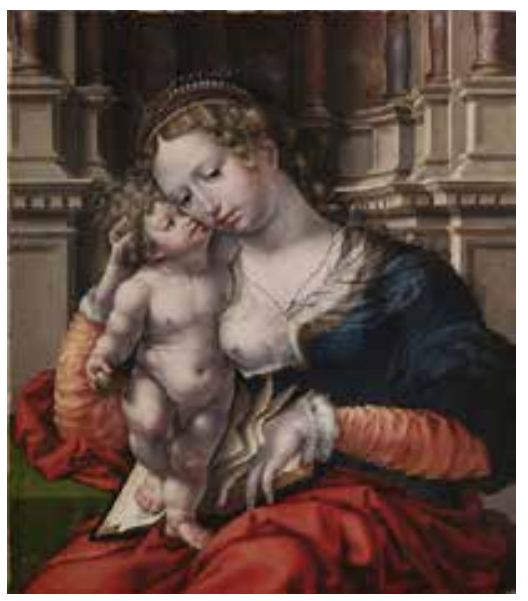

Fig 13 Jan Gossart, Virgin and Child, ca. 1527, oil on panel, $63 \times 50 \mathrm{~cm}$. Museo del Prado, Madrid, inv. no. 1930 (artwork in the public domain) 
Gossart. ${ }^{13}$ Although there is no documentation of this, the stylistic evidence does support the influence of the older master on the younger one. Indeed, the right half of the diptych of Cardinal Érard de la Marck and The Holy Family derives from Gossart's Prado Virgin and Child, ${ }^{14}$ even exaggerating the muscular, Herculean Christ Child beyond the model and the Mannerist tendencies of composition and form (compare figs. 12 and 13). In addition, Vermeyen's Judith appears to take inspiration from Gossart's Mary Magdalen (Museum of Fine Arts, Boston). ${ }^{15}$ Both are similar tightly cropped compositions, where at the left Judith boldly grasps her sword as the Magdalen embraces her unguent jar. The two women are dressed in a highly decorative style with jeweled adornments, elaborate headdresses, and braided hairstyles -- Judith's fluttering veil mimicking the Magdalen's trailing hair at the right. In particular, both women express an unnerving eroticism. As we shall see, there are also features of the painting techniques of Gossart and Vermeyen that link the two artists.

Some of the materials and techniques that Vermeyen employed in the Judith are strikingly similar to those of the Holy Family and the Cardinal. The three oak panels are of comparable size. ${ }^{16}$ It appears that the original format of the Judith panel has not been changed significantly, apart from being slightly trimmed on one side (fig. 14) ${ }^{17}$ It is difficult to determine for certain whether it was painted within a frame; some of the paint that approaches the edges of the panel is not original. ${ }^{18}$ The Holy Family also seems to be close to its original format and was painted while in a frame, as suggested by unpainted margins around all four edges (fig. 15). ${ }^{19}$

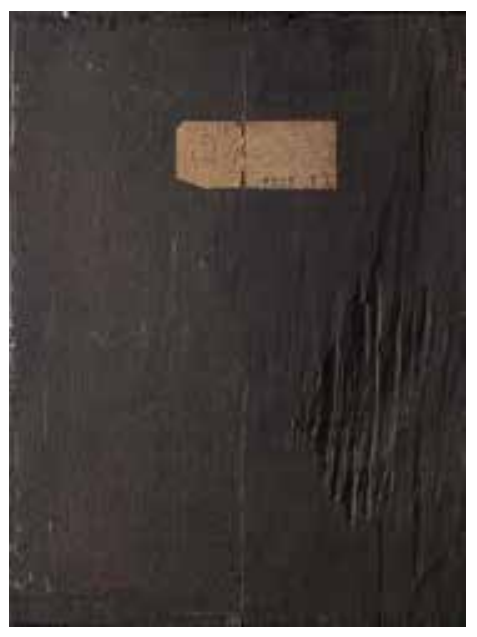

Fig 14 Jan Cornelisz. Vermeyen, verso of Judith with the Head of Holofernes (Photo: Paintings Conservation Department, Metropolitan Museum of Art)

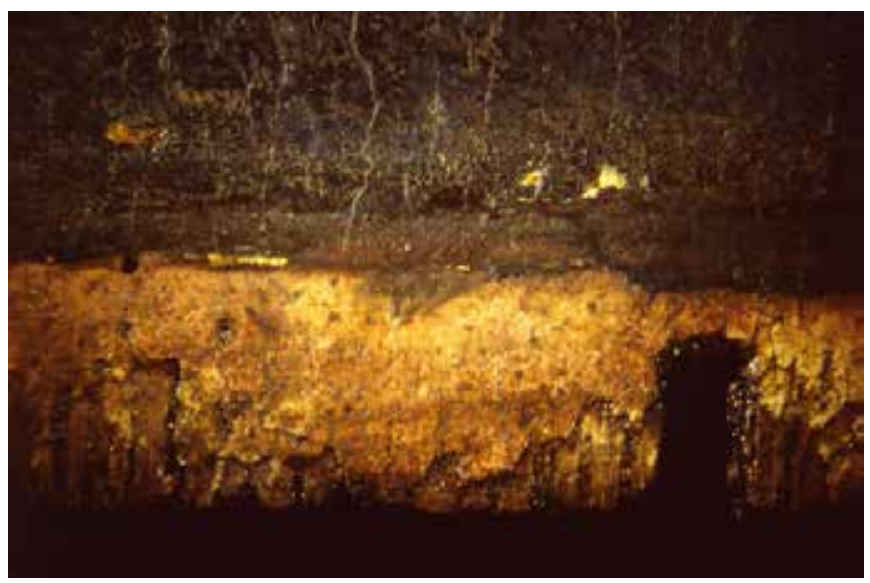

Fig 15 Jan Cornelisz. Vermeyen, microphoto of unpainted margin on the bottom edge, The Holy Family, 0.63x magnification

8 All three works have a white ground layer, and a typical composition for a ground from this period would be a mixture of chalk and glue. Under the microscope, fine parallel lines are visible in the ground of the Judith, especially in brown passages like her headdress, where the paint is abraded (fig. 16). Comparable lines can be found in the flesh tones of the Holy Family (fig. 17). Microscopic lines in the ground are not necessarily a specific or intentional part of Vermeyen's technique; they are often attributable to scraping marks made by a knife during the smoothing of the ground, or by a spreader used during the application of the ground..$^{20}$ They have been found in the works of other artists, including Jan Gossart. ${ }^{21}$ 


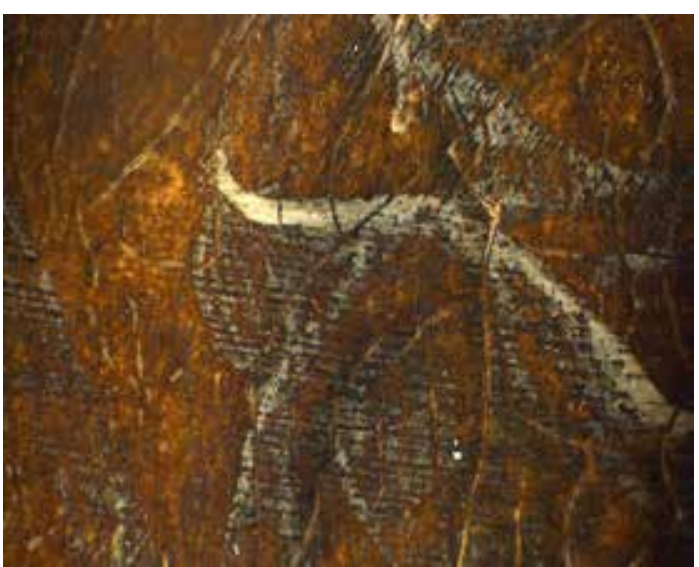

Fig 16 Jan Cornelisz. Vermeyen, microphoto showing parallel lines in the ground beneath the brown/green cloth, Judith with the Head of Holofernes, $5 x$ magnification

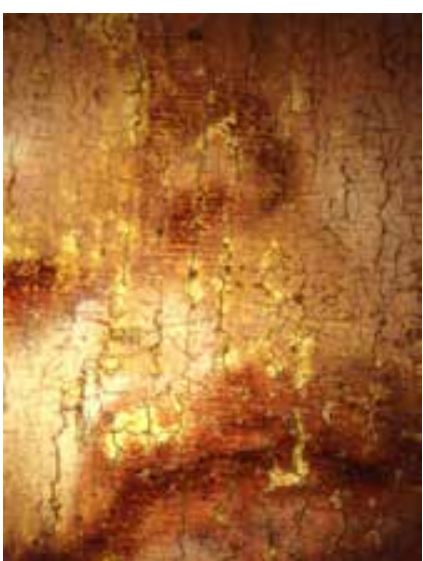

Fig 17 Jan Cornelisz. Vermeyen, microphoto showing parallel lines in the ground beneath Christ's face, The Holy Family, 0.63x magnification

9 Another intriguing technical feature that links the painting techniques of Vermeyen and Gossart is the application of a flesh-colored layer on top of the ground but beneath the paint layers: a so-called priming or intermediate layer. ${ }^{22}$ A rather opaque pink layer -- containing lead white, red lake, vermilion, and some black particles -- was found to be present beneath both the Holy Family and the Cardinal. ${ }^{23}$ It underlies the whole surface of both paintings, and it was applied before the underdrawing. ${ }^{24}$ The pink tone was very important for the very direct and efficient way in which Vermeyen built up the flesh tones. ${ }^{25} \mathrm{He}$ also let it shine through in the heavens in the Holy Family and in the Virgin's sleeve. Without a thorough technical overview of Vermeyen's oeuvre, it is difficult to know whether the all-over pink priming is a technique he used consistently, or whether it was used in an isolated case for the Holy Family and Cardinal paintings, perhaps in response to the technique of Jan Gossart. ${ }^{26}$

10 If the Judith indeed predates the two pendant paintings, perhaps it also precedes Vermeyen's experimentation with pink priming beneath the whole surface of the painting. Many parts of the Judith composition are based on a pink tone: particularly the flesh and the sleeves. The flesh tones are rather thinly and efficiently painted, relying on a pink base tone with thinly applied highlights and brown shadows on top; unfortunately these thin upper layers have become abraded over time and have been retouched in many places. Under the microscope, the base tone of Judith's skin seems to be made of a mixture of pigments: two different types of red (probably red lake and vermilion), alongside black and white particles (figs. 18, 19). ${ }^{27}$ This pigment mixture is very similar to the one used in the priming of the Holy Family and the Cardinal, although it should be noted that this is a relatively common composition for flesh tones in this period. To paint the body of the Christ Child in the Holy Family, Vermeyen used a very efficient and direct technique. He exploited the tone of the pink priming, and needed only to apply thin highlights and shadows on top and blend them together; this is very similar to the technique used in Judith's skin. ${ }^{28}$ However, it is unclear whether a pink priming layer underlies the entire surface of the Judith paintings; perhaps it is only isolated to the areas of flesh. Due to the condition of the painting, it is difficult to assess how far the pink base tone or intermediate layer extends. Small losses in the background and along the edges were examined under the microscope, and these did not appear to show a pink priming between the ground and paint layers. 


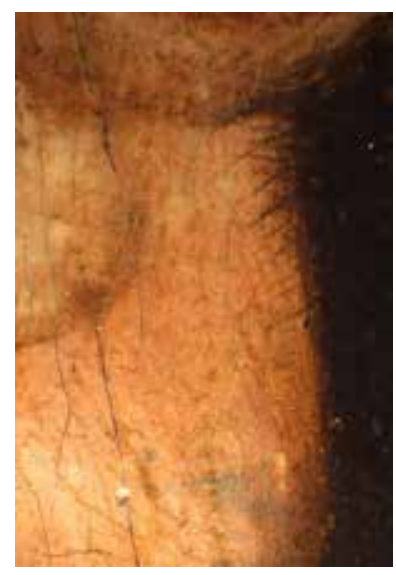

Fig 18 Jan Cornelisz. Vermeyen, microphoto showing pigments in the flesh of Judith's hand, and feathery brushstrokes between the hand and her clothing, Judith with the Head of Holofernes, $25 x$ magnification

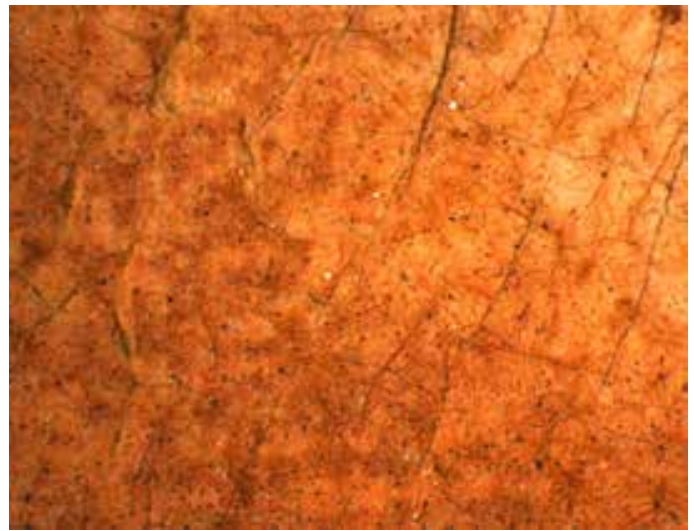

Fig 19 Jan Cornelisz. Vermeyen, microphoto showing pigments in the flesh of Judith's hand, Judith with the Head of Holofernes, 50x magnification

11 There are many similarities in paint application that can best be seen under the microscope, or in photomicrographs. In the Holy Family and the Cardinal, tiny hatched brushstrokes along the edges of fabrics give the impression of a hairy or wooly texture, especially along the edge of the Virgin's blue robe and the cardinal's hat (fig. 20). ${ }^{29}$ In the Judith painting, some areas -- eyelashes, eyebrows, and the border around her breastplate -- reveal similar refined parallel hatching (see fig. 18). A more blended form of feathery brushwork can be found within the shot silk fabric of her sleeves, which are described in greater detail below. This type of feathery brushwork, where one color is blended wet-in-wet into another with a light touch, connects Vermeyen's painting technique with that of Jan Gossart. ${ }^{30}$

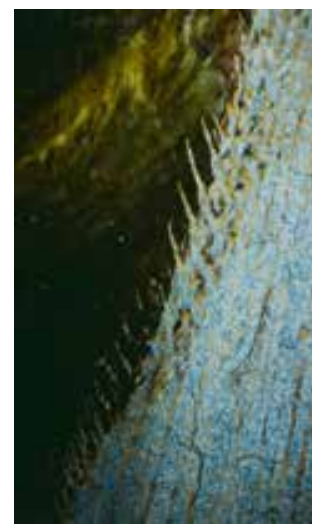

Fig 20 Jan Cornelisz. Vermeyen, microphoto of feathery brushstrokes on the edge of the Virgin's robe, The Holy Family, $1.25 x$ magnification

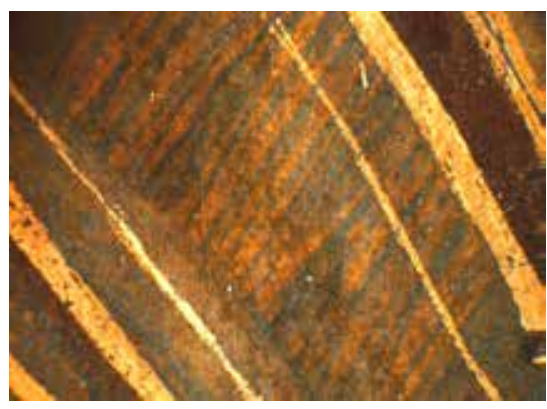

Fig 21 Jan Cornelisz. Vermeyen, microphoto of fringe of Judith's sleeve, Judith with the Head of Holfernes, $12.5 x$ magnification

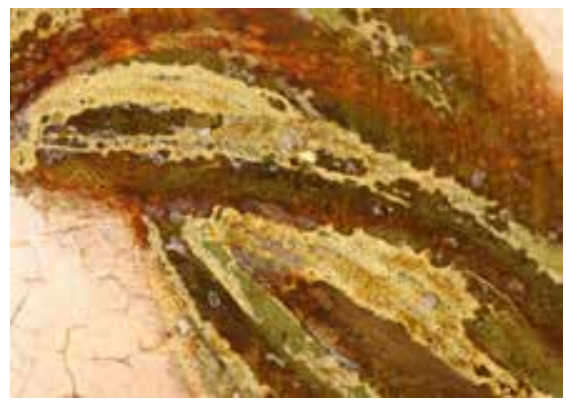

Fig 22 Jan Cornelisz. Vermeyen, microphoto of yellow highlight in the cloth around the Christ Child, The Holy Family, 1.25x magnification

12 Vermeyen often used glazes in lower layers of his painting, then applied fine details on top when these glazes were dry. This technique appears to have been used in the fringe at the top of Judith's sleeve: deft zigzags of blue paint were applied on top of a glazy pink underlayer, which shimmers through between the blue brushstrokes (fig. 21). Presumably after both of these colors were dry, Vermeyen applied dry yellow lines on top. He used a similar technique in Judith's fluttering head- 
scarf (see fig. 16). The distinctive color combination of a glazy (oil-rich) brown base with green and pale yellow highlights is also present in the cloth that the Virgin holds around the Christ Child in the Holy Family. Presumably both are meant to depict silky lightweight fabrics. In the yellow highlights, the paint seems to "resist" the layer underneath, probably because it was applied on top of a glazy underlayer that was relatively dry (fig. 22). ${ }^{31}$ In both paintings, it is possible that deterioration has caused changes in color, but examination under the microscope suggests that much of the brown glaze is indeed a brown paint rather than a discolored green. In the Holy Family, there are some remains of a greenish mid-tone.

13 Another interesting fabric is represented in Judith's sleeves. The combination of pink and green are likely meant to represent changeant, or shot silk. ${ }^{32}$ This type of fabric assumes one of two colors, depending on the angle of the viewer's eye to the surface of a given part of the textile. The position of the colors in the changeant sleeves in the Judith painting is accurately observed: Vermeyen used green for fabric folding away from the viewer at a sharp angle and dark pink for folds that are more parallel to the viewer. This optical sophistication is uncommon in paintings of this period, which often relied on formulas and visual "tricks" to paint shot silks. ${ }^{33}$ Although the sleeves in Judith with the Head of Holofernes are very damaged and most of the green highlights have been heavily retouched, Vermeyen's technique for painting shot silk is visible in a few areas under the microscope. ${ }^{34}$ On top of a glazy pink layer, he applied opaque pink and green tones. The edges of the opaque areas are feathered with tiny hatched brushstrokes. Where the two colors occasionally meet, they have been blended into each other in a back-and-forth motion (fig. 23). This back-and-forth effect executed with two colors while they are still wet was also observed in the Holy Family.

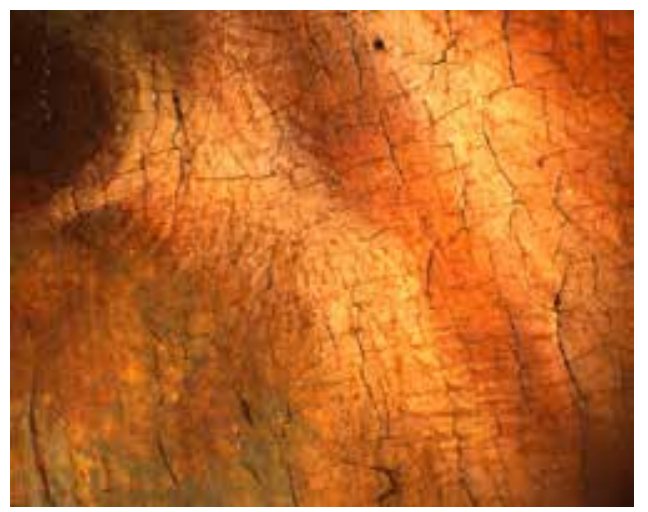

Fig 23 Jan Cornelisz. Vermeyen, microphoto of feathery brushstrokes in changeant fabric, Judith with the Head of Holofernes, 25x magnification

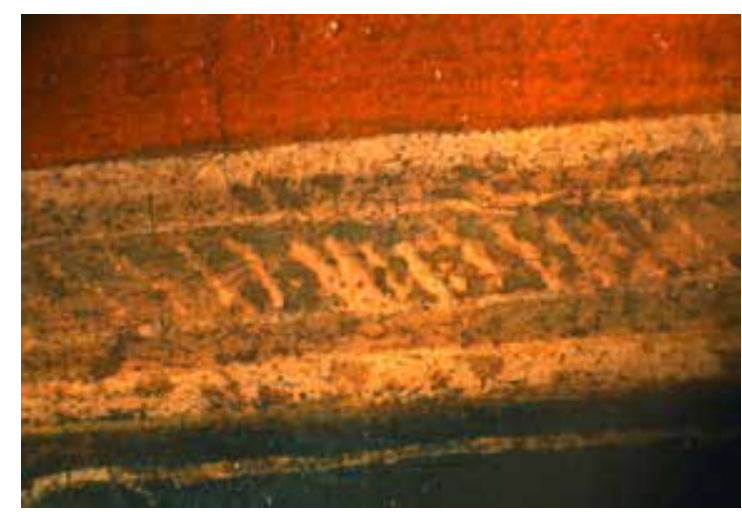

Fig 24 Jan Cornelisz. Vermeyen, microphoto of green underlayer beneath pink paint in the trim of Judith's bodice, Judith with the Head of Holofernes, $12.5 x$ magnification

14 In addition to the pink and green changeant sleeves, other combinations of pink and green seem to recur throughout the painting. For example, in the trim of Judith's breastplate, a green underlayer is visible under abraded pink paint (fig. 24). Remarkably, the background would also have played into this pink-and-green color combination: the area around the figure was originally an intense dark green. Several paint losses in the background and along the edges of the panel show remains of a green layer, which is now completely hidden beneath a flat black layer of paint. ${ }^{35}$ Assuming the background was originally a dark green, it would have created a dramatic yet harmonious contrast with the flesh tones. Perhaps its effect would have been similar to the curtain that 
connects the Cardinal and Holy Family paintings, and to the background of Vermeyen's portrait of Jean Carondelet from circa 1530 (Brooklyn Museum of Art). ${ }^{36}$

15 When considering for whom this painting of Judith, expressing female power, wisdom, and fortitude, may have been painted, a likely candidate comes to mind -- Margaret of Austria, regent of the Netherlands. It may well have been through Jan Gossart or perhaps Bernard Van Orley (ca. 1491/92-1542) that Vermeyen was introduced to Margaret, who held her court in Mechelen. He must have entered the service of Margaret in 1525, for a document of 1530 petitions the regent for back pay for a period of about five years, indicating that Vermeyen had already been working for her. ${ }^{37}$ During this time, Vermeyen seems to have been mostly engaged in making portraits of the royal family and other nobles, such as the Portrait of Cardinal Érard de la Marck that with the Holy Family formed a diptych which belonged to Margaret.

16 The importance of the widow Judith as a model of strength and feminine virtue for Margaret of Austria and the iconography of the Burgundian-Habsburg court cannot be underestimated. The reminders of Judith's importance as a just, vigorous, and brave ruler took many forms. Some of these were ephemeral, such as the tableaux vivants devoted to Judith that were performed at the official entries of princesses, such as Margaret of York, Mary of Burgundy, and Juana of Castile, into Netherlandish cities. ${ }^{38}$ Margaret of Austria owned a Judith tapestry (no longer extant) that was originally part of her trousseau for her marriage to Juan of Castile, and when she returned to Flanders after Juan's death, the tapestry accompanied her. ${ }^{39}$ Possibly commissioned by Margaret from Bernard van Orley (her court painter), although not mentioned in the inventory of her possessions, was a tapestry of the Triumph of Virtuous Women that survives only as a petit patron (Vienna, Albertina Museum, inv. no. 15463). ${ }^{40}$ Featured in the foreground before the triumphal all'antica chariot are Jael killing Sisera, Lucretia committing suicide, and Judith with the head of Holofernes on the tip of her sword. Margaret's court sculptor, Conrad Meit, produced one of the masterpieces of Renaissance sculpture, a Judith with the Head of Holofernes (Munich, Bayerische Nationalmuseum), circa 1525-28. Although it is not listed among Margaret's belongings, it certainly reflects courtly taste and was most likely commissioned by a woman for whom Judith was a noble exemplar. ${ }^{41}$

17 Margaret's library contained books on virtuous women, among them Giovanni Bocaccio's De femmes nobles et renomées (Paris, Bibliothèque nationale de France, ms. Fr. 12420). Judith has a featured role in one of the most influential texts of the late fifteenth and early sixteenth centuries, the Parement et triumphe des dames, written in 1493-94 by Olivier de la Marche. Here the author gives lessons to a noble lady of the virtues of humility, wisdom, loyalty, fidelity, and so forth in prose stories of famous virtuous women. Margaret of Austria owned an early version of the text, published between 1495 and 1500 (Brussels, Bibliothèque royale de Belgique, ms. 10961-70). ${ }^{42}$ In 1509, Agrippa of Nettesheim dedicated to Margaret his treatise De nobilitate et praecellentia foemini sexus, where he notes that Judith "depicted herself as an example of virtue, which should be imitated not only by women but also by men," 43

18 Barbara Welzel has pointed out that Judith was first considered as the ideal of the Christian woman ${ }^{44}$ but became as well an important figure of identification for princesses, serving as a political exemplum. ${ }^{45}$ Just as Judith saved her people from the Assyrians, so, too, did Margaret 
defend her people in a politically active role. Her success in this endeavor was acknowledged in a monumental woodcut by Robert Péril (Berlin, Staatliche Museen zu Berlin, Kupferstichkabinett, inv. no. 849-21), showing the genealogy of the Habsburgs, which praised Margaret as: "the Regent and sovereign of the Low countries, which she wisely ruled for Emperor Charles, her nephew; she opposed the enemy with the force of weapons and transferred the lands of Friesland, Utrecht and Overissel into the following of his majesty [Charles V]." ${ }^{46}$

19 In terms of Margaret's remarkable political acumen, a singular event comes to mind that may have a specific connection to Vermeyen's Judith with the Head of Holofernes. In August of 1529, around the time of the painting's presumed date, Jan Vermeyen accompanied Margaret to the signing of the so-called Paix des Dames or Ladies' Peace, otherwise known as the Peace of Cambrai: the most extraordinary diplomatic achievement of the regent's career. Meeting her sister-inlaw Louise of Savoy (mother of Francis I) almost in secret in Cambrai, Margaret -- representing her nephew Charles V -- negotiated a peace between the French and the Habsburgs. This treaty, which included the arranged marriage of Eleanor of Austria (sister to Charles V) to Francis I, ended, at least for a time, the fighting between the forces of King Frances I and Emperor Charles V. An obvious parallel exists between Margaret and Judith: two virtuous and powerful women, who managed to find a solution to the lust for battle of men and nations and create peace. Whether this painting commemorates a specific event or generally celebrates the heroic achievement of one woman, it is certainly a product of the milieu of Margaret of Austria's court.

\section{Acknowledgments}

The authors would like to thank: the conservation departments of the Frans Hals Museum, Haarlem, and the Metropolitan Museum of Art, New York; Joseph Baillio, George Bisacca, Dagmar Eichberger, Molly Faries, Jan Piet Filedt Kok, Charlotte Hale, Jack Horn, Sarah Kleiner, Mireille te Marvelde, M. Alan Miller, Femke Speelberg, Ilona van Tuinen, and the anonymous readers of the manuscript.

\section{List of Illustrations}

The microphotos were taken by the authors using an Olympus SZX12 microscope in conjunction with a Q-imaging MicroPublisher 5.0 RTV.

Fig 1 Jan Cornelisz. Vermeyen, Judith with the Head of Holofernes, ca. 1525-30, oil on panel, 63.5 x $47.3 \mathrm{~cm}$. Private collection (Photo: Paintings Conservation Department, Metropolitan Museum of Art)

Fig 2 Jan Cornelisz. Vermeyen, detail of monogram on the hilt of the sword, Judith with the Head of Holofernes, normal light (Photo: Paintings Conservation Department, Metropolitan Museum of Art)

Fig 3 Jan Cornelisz. Vermeyen, detail of monogram on the hilt of the sword, Judith with the Head of Holofernes, infrared reflectogram (Photo: Paintings Conservation Department, Metropolitan Museum of Art)

Fig 4 Jan Cornelisz. Vermeyen, Detail of monogram, The Holy Family, ca. 1530, oil on panel, 64 
$\mathrm{cm}$ x $54.5 \mathrm{~cm}$. Netherlands Cultural Heritage Agency (Rijksdienst voor het Cultureel Erfgoed), inv. no. NK 2595 (artwork in the public domain)

Fig 5 Jan Cornelisz. Vermeyen, detail of inscription on the shaft of the sword, Judith with the Head of Holofernes (Photo: Paintings Conservation Department, Metropolitan Museum of Art)

Fig 6 Jacob Cornelisz. van Oostsanen, detail of winged angel's head, Berlin Sketchbook, folio 13v. Kupferstichkabinett, Staatliche Museen zu Berlin, inv. no. 79 C 2a (Photo: Volker H. Schneider, Berlin) (artwork in the public domain)

Fig 7 Jacob Cornelisz. van Oostsanen, detail of dolphins, Berlin Sketchbook, folios 1v, 13v, and the top of 46v. Kupferstichkabinett, Staatliche Museen zu Berlin, inv. no. 79 C 2a (Photo: Volker H. Schneider, Berlin) (artwork in the public domain)

Fig 8 Details of headdresses from Ein frembds vnd wunderbars Kunstbuechlin (Strasbourg, 1538). The Metropolitan Museum of Art, New York, Rogers Fund, 1919, inv. no. 19.62.2. (artwork in the public domain)

Fig 9 Details of armor from Ein frembds vnd wunderbars Kunstbuechlin (Strasbourg, 1538). The Metropolitan Museum of Art, Rogers Fund, 1919 (inv. no. 19.62.2) (artwork in the public domain)

Fig 10 Details of hands from Ein frembds vnd wunderbars Kunstbuechlin (Strasbourg, 1538). The Metropolitan Museum of Art, Rogers Fund, 1919 (inv. no. 19.62.2) (artwork in the public domain)

Fig 11 Jan Cornelisz. Vermeyen, Cardinal Érard de la Marck, ca. 1530, oil on panel, $63.7 \mathrm{~cm}$ x 54.5 $\mathrm{cm}$. Rijksmuseum, Amsterdam, inv. no. SK-A-4069 (artwork in the public domain)

Fig 12 Jan Cornelisz. Vermeyen, Holy Family (fig. 4).

Fig 13 Jan Gossart, Virgin and Child, ca. 1527, oil on panel, 63 x $50 \mathrm{~cm}$. Museo del Prado, Madrid, inv. no. 1930 (artwork in the public domain)

Fig 14 Jan Cornelisz. Vermeyen, verso of Judith with the Head of Holofernes (Photo: Paintings Conservation Department, Metropolitan Museum of Art)

Fig 15 Jan Cornelisz. Vermeyen, microphoto of unpainted margin on the bottom edge, The Holy Family, 0.63x magnification

Fig 16 Jan Cornelisz. Vermeyen, microphoto showing parallel lines in the ground beneath the brown/green cloth, Judith with the Head of Holofernes, $5 \mathrm{x}$ magnification

Fig 17 Jan Cornelisz. Vermeyen, microphoto showing parallel lines in the ground beneath Christ's face, The Holy Family, 0.63x magnification 
Fig 18 Jan Cornelisz. Vermeyen, microphoto showing pigments in the flesh of Judith's hand, and feathery brushstrokes between the hand and her clothing, Judith with the Head of Holofernes, 25x magnification

Fig 19 Jan Cornelisz. Vermeyen, microphoto showing pigments in the flesh of Judith's hand, Judith with the Head of Holofernes, 50x magnification

Fig 20 Jan Cornelisz. Vermeyen, microphoto of feathery brushstrokes on the edge of the Virgin's robe, The Holy Family, 1.25x magnification

Fig 21 Jan Cornelisz. Vermeyen, microphoto of feathery brushstrokes in changeant fabric, Judith with the Head of Holofernes, 25x magnification

Fig 22 Jan Cornelisz. Vermeyen, microphoto of fringe of Judith's sleeve, Judith with the Head of Holofernes, 12.5x magnification

Fig 23 Jan Cornelisz. Vermeyen, microphoto of "back and forth" working in changeant fabric, Judith with the Head of Holofernes, 20x magnification

Fig 24 Jan Cornelisz. Vermeyen, microphoto of green underlayer beneath pink paint in the trim of Judith's bodice, Judith with the Head of Holofernes, 12.5x magnification

${ }^{1}$ Robert Genaille, "L'Oeuvre de Jean Bellegambe," Gazette des Beaux-Arts, $6^{\text {th }}$ ser., no. 87 (January 1976): 7, 28, no. 33, fig. 30. The known provenance of the painting is: Sir Robert Soame Jocelyn, $8^{\text {th }}$ Earl of Roden (1883-1956), Tollymore Park, Bryansford, County Down, Northern Ireland; acquired at his estate sale (London, Sotheby's, March 6, 1957, lot 173, as "Jean Bellegambe") by Colnaghi's, London; Thos. Agnew's and Sons, Ltd., London, by June 1957; sold to current owner. ${ }^{2}$ Infrared reflectography was carried out in the Paintings Conservation Department at the Metropolitan Museum of Art when the painting was studied on May 12, 2005. Equipment: Indigo Systems Merlin near infrared camera (InGaAs sensor range: 900-1700 nanometers) with a Nikon Micro-Nikkor 55mm lens, in conjunction with a National Instruments IMAQ PCI-1422 frame grabber card and IRvista 2.51 software. Our sincere thanks to Charlotte Hale for her assistance. ${ }^{3}$ See Het vroegste Amsterdamse schetsboek, Een zestiende-eeuws zakboekje uit het atelier van Jacob van Oostsanen (Berlin, Kupferstichkabinett, 79 C 2a), introduction and commentary by Ilona van Tuinen, with a contribution by Daantje Meuwissen and foreword by Holm Bevers (Oostsanen: Stichting Jacob Cornelisz van Oostanen, 2014). Our thanks to Ilona van Tuinen for discussing this book with us. An in-depth discussion of the authorship of the drawings in the sketchbook is forthcoming from Daantje Meuwissen.

${ }^{4}$ Van Tuinen and Meuwissen, Het vroegste Amsterdamse schetsboek, 29.

${ }^{5}$ See especially folio 14 of Eyn Newe kunstlich moetdelboech alle kunstner zu brachen ... (Cologne [Peter Quentel], 1532), with woodcut illustrations, Metropolitan Museum of Art, Harry Brisbane 
Fund, 1924 (inv. no. 24.29).

${ }^{6}$ An example of this book is in the Metropolitan Museum of Art, Rogers Fund, 1919 (inv. no. 19.62.2).

${ }^{7}$ Otto Benesch, “Jan Vermeyen als Bildnismaler," Münchner Jahrbuch der bildenden Kunst 6 (1929):12-22; and Kurt Steinbart, "Jan Cornelisz. Vermeyen," Marburger Jahrbuch für Kunstwissenschaft, 6 (1931): 83-113.

${ }^{8}$ H. J. Horn, Jan Cornelisz Vermeyen, Painter of Charles V and His Conquest of Tunis: Paintings, Etchings, Drawings, Cartoons and Tapestries (Doornspijk: Davaco, 1989), xii.

${ }^{9}$ Abbie Bagley-Young, “Jan Cornelisz. Vermeyen's Cardinal Erard de la Marck and The Holy Family: A Diptych Reunited?” Burlington Magazine 150, no. 1259 (2008): 76-82; Maryan W. Ainsworth, ed., Man, Myth, and Sensual Pleasures: Jan Gossart's Renaissance, the Complete Works (New York and New Haven: Metropolitan Museum of Art/Yale University Press, 2010), esp. 22-24, 83-86, 305-06, figs. 86-90,252-54); John Oliver Hand, Catherine A. Metzger, and Ron Spronk, Prayers and Portraits: Unfolding the Netherlandish Diptych, exh. cat. (Washington, D.C., National Gallery of Art, and Antwerp, Koninklijk Museum voor Schone Kunsten, 2006-07), 236-37, 238-39 (illus.), 299-300, 323-24 (technical appendix), cat. no. 35.

${ }^{10}$ Judith with the Head of Holofernes was studied together by the authors on March 8, 2012, in the Paintings Conservation Department of the Metropolitan Museum of Art.

${ }^{11}$ Mireille te Marvelde, conservator/restorer at the Frans Hals Museum, Haarlem, treated the Cardinal painting and contributed to the technical research. Abbie Vandivere (nee Bagley-Young) treated the Holy Family and carried out the research and examination of both paintings at the Frans Hals Museum.

${ }^{12}$ See note 10.

${ }^{13}$ Bob Haak, "Het portret van Erard de la Marck door Jan Cornelisz. Vermeyen," Bulletin van het Rijksmuseum 11, no. 1 (1963): 11-19; and Horn, Jan Cornelisz. Vermeyen, 5-7.

${ }^{14}$ This was already noted by Horn, Jan Cornelisz. Vermeyen, 6.

${ }^{15}$ Ainsworth, Man, Myth, and Sensual Pleasures, 22, 240-42, cat. 38.

${ }^{16}$ The Judith panel measures 63.5 x $47.3 \mathrm{~cm}$. The Holy Family and Cardinal panels measure approximately $64 \times 54.5 \mathrm{~cm}$. The format of the Cardinal was altered in a previous treatment: the edges were cut down and strips of wood were added when the painting was cradled.

${ }^{17}$ The Judith panel was examined with the help of George Bisacca and M. Alan Miller at the Metropolitan Museum. The left side, as seen from the back, may have been trimmed by $1-2 \mathrm{~mm}$. The panel is made of two vertical planks: the left plank was hand sawn, but the right plank was split unevenly. Indentations on the left plank and a scored circle at the top of the panel are unlikely to be panel marks. The thickness of the panel is inconsistent. An examination of the back of the panel reveals that the top is thicker, and the upper edge has been crudely "hacked," whereas the other edges have a smooth rabbet. The bottom edge has a gradual bevel. No dendrochronology was conducted on the Judith panel. Dendrochronology of the Holy Family and Cardinal panels suggested plausible production dates of 1528 and 1519 (Hand, Metzger, and Spronk, Prayers and Portraits, 299).

18 The overpainted background is described later in this paper.

${ }^{19}$ The verso the pendant paintings have been altered: the Cardinal was thinned and cradled. The Holy Family has not been thinned but has been subjected to a number of repairs and alterations. Neither appears to have changed significantly in format. After the ground was applied over the whole surface of the Holy Family panel, it appears that a frame masked approximately $1 \mathrm{~cm}$ 
around all four edges, then the composition was painted. This is confirmed by the presence of a barbe where the paint layer ends. However, in the top left corner, the peach-colored brushstrokes have feathery edges, suggesting this area was painted before the edges were masked off. ${ }^{20}$ Lines made spreading of the ground were mentioned in relation to Rogier van der Weyden's Altarpiece of the Seven Sacraments: Marie Postec, "Technical Reconstitutions Based on 'The Seven Sacraments' by Rogier van der Weyden: An Experimental Approach," Rogier van der Weyden in Context: Papers Presented at the 17th Symposium for the Study of Underdrawing and Technology in Painting, Leuven, 22-24 October 2009, ed. Lorne Campbell, Jan Van der Stock, Catherine Reynolds, and Lieve Watteuw (Leuven: Peeters, 2012), 148-49.

${ }^{21}$ Ainsworth, Man, Myth, and Sensual Pleasures, 71.

${ }^{22}$ Hand, Metzger and Spronk, Prayers and Portraits, no. 35, 299-300 (and technical appendix on pp. 323-24), refer to it as a "peach-colored intermediate layer." On the subtle pale pinkish layer sometimes employed by Gossart as a mid-tone for the flesh areas, see Ainsworth, Man, Myth, and Sensual Pleasures 85-86. The very prominent peach-colored underlayer in the flesh tones of Saint Donatian (Musées des Beaux-Arts, Tournai) and Jean Carondelet (Nelson-Atkins Museum of Art, Kansas City) led Ainsworth to question the attribution of these two paintings to Gossart and instead to suggest that they may be early works by Vermeyen, whose Portrait of Érard de la Marck and Portrait of Jean Carondelet (Brooklyn Museum, New York), both of ca. 1530, show this feature (see Ainsworth, Man, Myth, and Sensual Pleasures, 86, figs. 86-90). For a discussion of pink intermediate layers used by other painters and related terminology, see Abbie Vandivere, "In Search of Van Mander's Primuersel: Intermediate Layers in Early Netherlandish Paintings," ICOM-CC 16 th Triennial Conference Preprints, Lisbon, 19-23 September 2011, ed. J. Bridgland (Lisbon: Critério - Artes Gráficas, Lda, 2011), 2.

${ }^{23}$ Some, but not all, of the samples included black particles. This could suggest that the pink layer varied somewhat in tone or that black was a minor component. Also, some samples showed more vermilion than red lake, and others show the opposite. See cross-sections illustrated in Bagley-Young, "Jan Cornelisz. Vermeyen's Cardinal Erard de la Marck," 80, fig. 8.

${ }^{24}$ This sequence -- underdrawing on top of a pinkish intermediate layer -- also occurs in paintings by Gossart and Jan van Scorel, who both visited Italy (Ainsworth, Man, Myth, and Sensual Pleasures, 71, and Molly Faries, "Jan van Scorel's Drawing and Painting Technique," in Catalogue of Paintings: 1363-1600; Centraal Museum Utrecht, ed. Liesbeth M. Helmus and Molly Faries (Utrecht: Centraal Museum, 2011), 27.

${ }^{25}$ Vandivere, "In Search of Van Mander's Primuersel," 5.

${ }^{26}$ A technical examination conducted by Abbie Vandivere and Arie Wallert showed that Vermeyen did not use a pink priming in The Marriage At Cana, ca. 1530, Rijksmuseum, Amsterdam, inv. no. SK-A-4820. Few other paintings by Vermeyen have so far been examined or sampled. For the selective use of a pink underlayer in paintings attributed both to Gossart and to Vermeyen, see notes 22 and 25 above.

${ }^{27}$ More white was added to the mixture in the highlights. The skin tone of the dead man, Holofernes, included blue pigments in addition to the aforementioned mixture.

${ }^{28}$ Vandivere, "In Search of Van Mander's Primuersel," 5.

${ }^{29}$ Illustrated in Bagley-Young, "Jan Cornelisz. Vermeyen's Cardinal Erard de la Marck," 80, figs 10 and 11 .

${ }^{30}$ Ainsworth, Man, Myth, and Sensual Pleasures, 86.

${ }^{31}$ No paint samples have been taken from these areas of drapery. The bubbles in the yellow high- 
light may be the result of saponification in lead-tin yellow and/or lead white.

${ }^{32}$ Mark Clarke and Abbie Vandivere, "Purpura and Proto-Changeant: The Earliest Representations of Shot Silk Fabrics," ICOM-CC $16^{\text {th }}$ Triennial Conference Preprints, Lisbon, 19-23 September 2011, ed. J. Bridgland (Lisbon: Critério - Artes Gráficas, Lda, 2011); and Abbie Vandivere and Mark Clarke "Changing Drapery, Recipes and Practice," Postprints of the conference Vision and Material: Interaction between Art and Science in Jan van Eyck's Time, Vlaams Academisch Centrum, Brussels, Belgium, November 2010, ed. Marc De Mey, Maximiliaan P. J. Martens, and Cyriel Stroo (Brussels: KVAB Press, 2012), 235-53.

${ }^{33}$ One of the few artists who painted iridescent changeant-like fabrics accurately was Marinus van Reymerswaele; for example, a diaphanous fabric in the Calling of Saint Matthew (ca. 1530, Thyssen-Bornemisza collection, Madrid), described in Vandivere, "In Search of Van Mander's Primuersel," 6. Stylistic connections to his paintings have previously been noted; for example, Judith's facial features have been compared to the Virgin in Reymerswaele's Madonna and Child, ca. 1511 (information from Wildenstein \& Co., New York).

${ }^{34}$ Most of the green areas appear "murky" under the microscope and cover craquelure and areas of damage. Part of Judith's sleeve is depicted on top of the stone in the bottom right; there the colors (particularly the intense red of the glaze) seem better preserved.

${ }^{35}$ Other reasons to believe that the background has been overpainted are its lack of modeling, the fact that it covers losses and flaking paint, that it was applied after all of the other adjacent areas of color, and that green paint is visible in an abraded area of the sword.

${ }^{36}$ The portrait with the green background is illustrated in Ainsworth, Man, Myth, and Sensual Pleasures, 85, fig. 90 (Jan Cornelisz. Vermeyen, Jean Carondelet, ca. 1530, oil on panel, 78 x 62.2 $\mathrm{cm}$. Brooklyn Museum, New York, Gift of Horace O. Havermeyer [inv. no. 47.76]).

${ }^{37}$ Steinbart, Jan Cornelisz. Vermeyen, 84-86, in turn based on a document published by Jules Houdoy, "Marguerite d'Autriche, l'église de Brou: Les artistes de la Renaissance de Flandres," Gazette des Beaux-Arts 14 (1872): 515-18. For a discussion of this document, see Horn, Jan Cornelisz. Vermeyen, 59-60, n. 46, 61, n. 52.

${ }^{38}$ Barbara Welzel, "Widowhood: Margaret of York and Margaret of Austria," in Women of Distinction Margaret of York / Margaret of Austria, exh. cat., ed. Dagmar Eichberger, (Mechelen, Schepenhuis Museum, 2005), 105, fig. 8.

39 “...dos panos de tapiceria grandes de sala rricos de oro, de la estoria de Alafermes [Holofernes]," inventory of Margarita de Austria, "Inventario de jooyas, perlas, piedras preciosas y otros objetos," 28 de septiembre de 1499, Archivo General de Simancas, Valladolid, Patronato Real, leg. 56-9 (p. 24, f12v, ij) in Dagmar Eichberger, "Margaret of Austria and the Documentation of Her Collection in Mechelen," in The Royal Inventories of Charles V and the Imperial Family, 3 vols., ed. F. Checa Cremades (Madrid: Fernando Villaverde Ediciones, 2010), 3:2380.

${ }^{40}$ Dagmar Eichberger, Leben mit Kunst, Wirken durch Kunst: Sammelwesen und Hofkunst unter Margarete von Österreich, Regentin der Niederlande (Turnhout: Brepols, 2002), 45-46.

${ }^{41}$ See Jens Ludwig Burk's entry on this statue in Conrat Meit Bildhauer der Renaissance, exh. cat., edited by Renate Eikelmann (Munich, Bayerischen Nationalmuseum, 2006-7), 76-79, cat. no. 3. ${ }^{42}$ For a summary of the library of Margaret of Austria and also the literature written for her, see Anne-Marie Legaré, "La librairye de Madame’ Two Princesses and Their Libraries"” and Marie Madeleine Fontaine, "Olivier de la Marche and Jean Lemaire de Belge," in Women of Distinction, ed. Eichberger, 206-19, 221-29.

${ }^{43}$ Welzel, "Widowhood," in Women of Distinction, ed. Eichberger, 105, 258-59, cat. no. 98 (Henri 
Installé).

${ }^{44}$ In regard to this iconography, especially in relation to Le Mystère de Judith et Holofernés of ca. 1500 thought to be by Jean Molinet, see Kathleen M. Llewellyn, "The Example of Judith in Early Modern French Literature," in The Sword of Judith, Judith Studies Across the Disciplines, ed. Kevin

R. Brine, Elena Ciletti, and Henricke Lähnemann (Cambridge: Open Book Publishers, 2010), 213-25.

${ }^{45}$ Welzel, "Widowhood," in Women of Distinction, ed. Eichberger, 103-13, esp. 105.

${ }^{46}$ Eichberger, Leben mit Kunst, 146-47; Dagmar Eichberger, "Illustrierte Festzüge für das Haus Habsburg-Burgund: Idee und Wirklichkeit," in Hofkultur in Frankreich und Europa im Spätmittelalter: La culture de cour en France et en Europe à la fin du Moyen Âge, ed. Christian Freigang and Jean-Claude Schmitt (Berlin: Akademie-Verlag, 2005), 73-98; and Welzel, "Widowhood," in Women of Distinction, ed. Eichberger, 80-81, 105-06, cat. no. 15 (Mark McDonald).

\section{Bibliography}

Ainsworth, Maryan W., ed. Man, Myth, and Sensual Pleasures: Jan Gossart's Renaissance, the Complete Works. New York and New Haven: Metropolitan Museum of Art/Yale University Press, 2010.

Bagley-Young, Abigail. “Jan Cornelisz. Vermeyen's 'Cardinal Erard de la Marck' and 'Holy Family': A Diptych Reunited?” Burlington Magazine 150, no. 1259 (February 2008): 76-82.

Benesch, Otto. “Jan Vermeyen als Bildnismaler.” Münchner Jahrbuch der bildenden Kunst 6 (1929):12-22.

Clarke, Mark, and Abbie Vandivere. "Purpura and Proto-Changeant: The Earliest Representations of Shot Silk Fabrics." In ICOM-CC $16^{\text {th }}$ Triennial Conference Preprints, Lisbon, 19-23 September 2011, edited by J. Bridgland. Lisbon: Critério - Artes Gráficas, Lda, 2011.

Eichberger, Dagmar. Leben mit Kunst, Wirken durch Kunst: Sammelwesen und Hofkunst unter Margarete von Österreich, Regentin der Niederlande. Turnhout: Brepols, 2002.

Eichberger, Dagmar. "Illustrierte Festzüge für das Haus Habsburg-Burgund: Idee und Wirklichkeit." In Hofkultur in Frankreich und Europa im Spätmittelalter: La culture de cour en France et en Europe à la fin du Moyen Âge, edited by Christian Freigang and Jean-Claude Schmitt, 73-98. Berlin: Akademie-Verlag, 2005.

Eichberger, Dagmar. "Margaret of Austria and the Documentation of Her Collection in Mechelen." In The Royal Inventories of Charles $V$ and the Imperial Family, 3 vols., edited by F. Checa Cremades, 3:2351-63. Madrid: Fernando Villaverde Ediciones, 2010.

Eichberger, Dagmar, ed. Women of Distinction Margaret of York / Margaret of Austria. Exh. cat. Schepenhuis Museum, Mechelen, 2005.

Eikelmann, Renate, ed. Conrat Meit Bildhauer der Renaissance. Exh. cat. Munich, Bayerisches Nationalmuseum, 2006. 
Ein frembds vnd wunderbars Kunstbuechlin. Strasbourg, 1538.

Eyn Newe kunstlich moetdelboech alle kunstner zu brachen ... Cologne [Peter Quentel], 1532 (with woodcut illustrations).

Faries, Molly. “ Jan van Scorel's Drawing and Painting Technique." In Catalogue of Paintings: 1363-1600; Centraal Museum Utrecht, edited by Liesbeth M. Helmus and Molly Faries, 23-42. Utrecht: Centraal Museum, 2011.

Fontaine, Marie Madeleine. "Olivier de la Marche and Jean Lemaire de Belge," In Women of Distinction Margaret of York / Margaret of Austria, edited by Dagmar Eichberger, 221-29. Exh. cat. Schepenhuis Museum, Mechelen, 2005.

Genaille, Robert. "L'Oeuvre de Jean Bellegambe." Gazette des Beaux-Arts, $6^{\text {th }}$ ser., no. 87 (January 1976): 221-29.

Haak, Bob. "Het portrait van Erard de la Marck door Jan Cornelisz. Vermeyen." Bulletin van het Rijksmuseum 11, no. 1 (1963): 11-19.

Hand, John Oliver, Catherine A. Metzger, and Ron Spronk. Prayers and Portraits: Unfolding the Netherlandish Diptych. Exh. cat. Washington, D.C., National Gallery of Art, and Antwerp, Koninklijk Museum voor Schone Kunsten. New Haven: Yale University Press, 2006.

Het vroegste Amsterdamse schetsboek, Een zestiende-eeuws zakboekje uit het atelier van Jacob van Oostsanen (Berlin, Kupferstichkabinett, 79 C 2a). Introduction and commentary by Ilona van Tuinen, with a contribution by Daantje Meuwissen and foreword by Holm Bevers. Oostsanen: Stichting Jacob Cornelisz van Oostsanen, 2014.

Horn, Hendrik J. Jan Cornelisz Vermeyen, Painter of Charles V and His Conquest of Tunis: Paintings, Etchings, Drawings, Cartoons and Tapestries. Doornspijk: Davaco, 1989.

Houdoy, Jules. "Marguerite d'Autriche, l'église de Brou: Les artistes de la Renaissance de Flandres." Gazette des Beaux-Arts 14 (1872): 515-18.

Legaré, Anne-Marie. “La librairye de Madame' Two Princesses and Their Libraries." In Women of Distinction Margaret of York / Margaret of Austria, edited by Dagmar Eichberger, 207-19. Exh. cat. Schepenhuis Museum, Mechelen, 2005.

Llewellyn, Kathleen M. “The Example of Judith in Early Modern French Literature." In The Sword of Judith, Judith Studies Across the Disciplines, edited by Kevin R. Brine, Elena Ciletti, and Henricke Lähnemann, 213-25. Cambridge: Open Book Publishers, 2010.

Postec, Marie. “Technical Reconstitutions Based on 'The Seven Sacraments' by Rogier van der Weyden: An Experimental Approach.” In Rogier van der Weyden in Context: Papers Presented at the 17th Symposium for the Study of Underdrawing and Technology in Painting, Leuven, 22-24

JHNA 6:2 (Summer 2014) 
October 2009, edited by Lorne Campbell, Jan Van der Stock, Catherine Reynolds, and Lieve Watteuw, 147-57. Leuven: Peeters, 2012.

Steinbart, Kurt. “Jan Cornelisz. Vermeyen.” Marburger Jahrbuch für Kunstwissenschaft, 6 (1931): 83-113.

Vandivere, Abbie. "In Search of Van Mander's Primuersel: Intermediate Layers in Early Netherlandish Paintings." In ICOM-CC $16^{\text {th }}$ Triennial Conference Preprints, Lisbon, 19-23 September 2011, edited by J. Bridgland, Lisbon: Critério - Artes Gráficas, Lda, 2011.

Vandivere, Abbie, and Mark Clarke. "Changing Drapery, Recipes and Practice." Postprints of the conference Vision and Material: Interaction between Art and Science in Jan van Eyck'sTime, Vlaams Academisch Centrum, Brussels, Belgium, November 2010, edited by Marc De Mey, Maximiliaan P. J. Martens, and Cyriel Stroo, 235-53 Brussels: KVAB press, 2012.

Vermandere, Els. “Vermeyen, Jan Cornelisz." In Dictionary of Art. New York: Groves's Dictionaries, 1996.

Welzel, Barbara. "Widowhood: Margaret of York and Margaret of Austria." In Women of Distinction Margaret of York / Margaret of Austria, edited by Dagmar Eichberger, 103-13. Exh. cat. Schepenhuis Museum, Mechelen, 2005.

Recommended Citation:

Maryan Ainsworth and Abbie Vandivere, "Judith with the Head of Holofernes: Jan Cornelisz Vermeyen's Earliest Signed Painting, " JHNA 6:2 (Summer 2014), D0I: 10.5092/jhna.2014.6.2.2 